\title{
Binding, Uptake, and Intracellular Trafficking of Phosphorothioate-modified Oligodeoxynucleotides
}

\author{
Christian Beltinger, ${ }^{*}$ H. Uri Saragovi, ${ }^{*}$ Robert M. Smith, ${ }^{*}$ Lynne LeSauteur, ${ }^{*}$ Neelima Shah, ${ }^{*}$ Larry DeDionisio, ${ }^{*}$ \\ Laura Christensen, ${ }^{*}$ Annette Raible, ${ }^{*}$ Leonard Jarett, ${ }^{*}$ and Alan M. Gewirtz ${ }^{* 1}$ \\ * Departments of Pathology and Laboratory Medicine, and 'Internal Medicine, University of Pennsylvania School of Medicine, \\ Philadelphia, Pennsylvania, 19104; ${ }^{\ddagger}$ Department of Pharmacology and Therapeutics, McGill University, Montreal, PQ, Canada, \\ H3G1Y6; and ${ }^{\ddagger}$ Lynx Therapeutics, Hayward, California 94545
}

\begin{abstract}
An enhanced appreciation of uptake mechanisms and intracellular trafficking of phosphorothioate modified oligodeoxynucleotides (P-ODN) might facilitate the use of these compounds for experimental and therapeutic purposes. We addressed these issues by identifying cell surface proteins with which P-ODN specifically interact, studying P-ODN internalization mechanisms, and by tracking internalized $P$ ODN through the cell using immunochemical and ultrastructural techniques. Chemical cross-linking studies with a biotin-labeled P-ODN ( ${ }^{b}$ P-ODN), revealed the existence of five major cell surface P-ODN binding protein groups ranging in size from $\sim 20-143 \mathrm{kD}$. Binding to these proteins was competitively inhibited with unlabeled P-ODN, but not free biotin, suggesting specificity of the interactions. Additional experiments suggested that binding proteins likely exist as single chain structures, and that carbohydrate moieties may play a role in P-ODN binding. Uptake studies with ${ }^{35} \mathrm{~S}$-labeled $\mathrm{P}$-ODN revealed that endocytosis, mediated by a receptor-like mechanism, predominated at P-ODN concentrations $<1 \mu \mathrm{M}$, whereas fluid-phase endocytosis prevailed at higher concentrations. Cell fractionation and ultrastructural analysis demonstrated the presence of ODN in clathrin coated pits, and in vesicular structures consistent with endosomes and lysosomes. Labeled ODN were also found in significant amounts in the nucleus, while none was associated with ribosomes, or ribosomes associated with rough endoplasmic reticulum (ER). Since nuclear uptake was not blocked by wheat germ agglutinin or concanavalin A, a nucleoporin independent, perhaps diffusion driven, import process is suggested. These data imply that antisense DNA may exert their effect in the nucleus. They also suggest rational ways to design ODN which might increase their efficiency. (J. Clin. Invest. 1995. 95:1814-1823.) Key words: oligodeoxynucleotides • antisense DNA • gene therapy • receptors • nuclear import
\end{abstract}

C. Beltinger's present address is Division of Oncology, Children's Hospital of Philadelphia, 34th Street and Civic Center Boulevard, Philadelphia PA, 19104. Address correspondence to Alan M. Gewirtz, Room 513B-BRB I, University of Pennsylvania School of Medicine, 422 Currie Blvd, Philadelphia PA, 19104. Phone: 215-898-4499; FAX: 215573-2078.

Received for publication 1 August 1994 and in revised form 21 October 1994.

J. Clin. Invest.

(c) The American Society for Clinical Investigation, Inc.

$0021-9738 / 95 / 04 / 1814 / 10 \quad \$ 2.00$

Volume 95, April 1995, 1814-1823

\section{Introduction}

Antisense oligodeoxynucleotides (ODN) ${ }^{1}$ have been widely employed to disrupt gene function in a diverse array of in vitro culture systems $(1,2)$. To a more limited extent they have also been employed for in vivo experimentation (e.g., 3-7). Quite recently, nuclease resistant phosphorothioate modified ODN (PODN) have also been used clinically to treat patients with acute and chronic leukemias $(8,9)$. Human trials using ODN to treat genital warts and patients with AIDS are also ongoing (10). These forays into the clinic have further enhanced speculation that the antisense strategy for disrupting gene function may prove a useful addition to the treatment of these and other disorders in the not too distant future $(10,11)$. Nevertheless, inefficient cellular uptake of DNA and lack of a precise understanding of how and where antisense DNA perturbs gene expression imposes limits on the therapeutic and experimental usefulness of these compounds. We therefore sought to identify cell surface proteins with which P-ODN interact, investigate PODN internalization mechanisms and, by utilizing immunochemical and ultrastructural techniques, track internalized PODN through the cell to understand more completely where antisense molecules and their targets likely come into contact. The results of our studies suggest that there are numerous cell surface proteins which bind P-ODN in an apparently specific manner. Our studies also suggest uptake of bound DNA is concentration dependent with endocytosis mediated by a receptorlike mechanism predominating at low concentration $(<1 \mu \mathrm{M})$ and fluid phase endocytosis becoming more prominent above this concentration. Finally, once internalized, P-ODN move from the endosomal compartment into the cytoplasm and thence into the nucleus. During this transit, no convincing evidence was found to suggest that ODN associated with rough endoplasmic reticulum or with free ribosomes. These data suggest that the "antisense effect" may well occur in the nucleus and may therefore prove useful in the design of more effective molecules.

\section{Methods}

Oligodeoxynucleotides. P-ODN corresponding to the reverse complementary sequence of c-myb mRNA codons 2-9 were synthesized as previously described $(3,6)$. A 5 '-biotin labeled derivative of the $P$ ODN ( ${ }^{\mathrm{P} P-O D N}$ ) c-myb 24-mer was synthesized and HPLC purified using BioTEG phosphoramidite (Glen Research, Sterling, VA) (12). The final product was shown to be $92 \%$ pure by capillary electrophoresis

1. Abbreviations used in this paper: ${ }^{\mathrm{P}} \mathrm{P}-\mathrm{ODN}$, Biotin labeled P-ODN; $\mathrm{BS}^{3}$, bis(sulfosuccinimidyl) suberate; DSP, dithiobis(succinimidylpropionate); DSS, disuccinimidyl suberate; ER, endoplasmic reticulum; ODN, oligodeoxynucleotides; P-ODN, Phosphorothioate modified ODN. 
using a column and conditions optimized for phosphorothioates (13). A 5 '-fluorescein labeled derivative was similarly synthesized and HPLC purified using 6-FAM amidite (Applied Biosystems, Foster City, CA) (14). This material was $58.7 \%$ pure by capillary electrophoresis. The major contaminant $(25.8 \%)$ of the fluorescein labeled DNA was unlabeled full-length P-ODN. ${ }^{35}$ S-labeled P-ODN 24-mer was synthesized and purified as described (15).

Cells. K562 human leukemia cells were grown in RPMI 1640 (GIBCO-BRL, Gaithersburg, MD) with $10 \%$ bovine calf serum (GIBCO-BRL) at $37^{\circ} \mathrm{C}$ in $5 \% \mathrm{CO}_{2}$. HS294T human melanoma cells were grown in Dulbecco's modified medium (GIBCO-BRL) with $10 \%$ bovine calf serum (GIBCO-BRL) at $37^{\circ} \mathrm{C}$ in $5 \% \mathrm{CO}_{2}$.

Uptake of ${ }^{35}$ S-labeled P-ODN and ${ }^{14} \mathrm{C}$-sucrose in $\mathrm{K} 562$ cells. $\mathrm{K} 562$ cells $\left(2 \times 10^{7} / \mathrm{ml}\right)$ were incubated for $6 \mathrm{~h}$ at $37^{\circ} \mathrm{C}$ in RPMI 1640 (GIBCO-BRL) with various concentrations of either ${ }^{14} \mathrm{C}$-sucrose (specific activity $621 \mathrm{mCi} / \mathrm{mmol}$; Amersham, Arlington Heights, IL) or ${ }^{35}$ S-labeled P-ODN (specific activity $6.96 \times 10^{6} \mathrm{cpm} / \mu \mathrm{mol}$ ). After incubation the cells were washed three times in PBS. The washes were added to scintillation fluid (In-Flow BD; IN/US Systems, Fairfield, NJ) and analyzed in a scintillation counter. The cell pellet was lysed with a lysis buffer ( $150 \mathrm{mM} \mathrm{NaCl}, 50 \mathrm{mM}$ TRIS pH 8.0, 0.5\% NP-40), added to scintillation fluid and analyzed in a scintillation counter.

Chemical cross-linking of surface bound P-ODN. Exponentially growing $\mathrm{K562}$ cells $\left(2 \times 10^{7}\right.$ cells $\left./ \mathrm{ml}\right)$ were washed and resuspended in $0.5 \mathrm{ml}$ phosphate buffered saline (PBS). Cells were incubated ( 30 $\left.\min , 4^{\circ} \mathrm{C}\right)$ with ${ }^{\mathrm{b}} \mathrm{P}-\mathrm{ODN}(23 \mathrm{nM})$ in the presence or absence of a 500 fold excess $(25 \mu \mathrm{g})$ of non-biotinylated P-ODN and in the presence or absence of a $2 \times 10^{6}$ fold excess of d-Biotin. Cells were washed once to remove unbound ${ }^{\mathrm{b}} \mathrm{P}-\mathrm{ODN}$ after which surface bound material was cross-linked $\left(14^{\circ} \mathrm{C} ; 15 \mathrm{~min}\right)$ with $1-2 \mathrm{mM}$ bis (sulfosuccinimidyl) suberate $\left(\mathrm{BS}^{3}\right), 1-2 \mathrm{mM}$ disuccinimidyl suberate (DSS), or dithiobis (succinimidylpropionate) (DSP) (Pierce, Rockford, IL) as described (16). Excess cross-linker was quenched by washing the cells twice with $10 \mathrm{mM}$ ammonium acetate in ice cold PBS.

Biochemical analysis of P-ODN binding proteins. Membrane proteins from cross-linked cells were lysed in detergent buffer $(10 \mathrm{mM}$ Tris-HCI, $\mathrm{pH} 7.6,0.6 \mathrm{M} \mathrm{NaCl}, 10 \mu \mathrm{g} / \mathrm{ml}$ each of leupeptin and aprotinin, $1 \mathrm{mM}$ PMSF, and 2\% NP-40) followed by removal of cell nuclei and organelles by centrifugation $(15 \mathrm{~min}, 14,000 \mathrm{~g}$ ). Unfractionated, whole cell detergent lysates were subjected to SDS-PAGE and Western blotted to PVDF membranes $\left(1 \times 10^{6}\right.$ cell equivalents/lane $)$. Material crosslinked to ${ }^{b} \mathrm{P}-\mathrm{ODN}$ was detected on Western blots with horse radish peroxidase enzyme (HRP) coupled to avidin (Avidin-HRP) using the Enhanced Chemoluminescence kit as directed by the manufacturer (GIBCO-BRL).

${ }^{\mathrm{b}} \mathrm{P}-\mathrm{ODN}$ binding proteins were directly analyzed by performing similar cross-linking experiments with metabolically labeled cells. In these experiments, K562 cells were first labeled by overnight culture with $\left[{ }^{35} \mathrm{~S}\right]$ methionine and $\left[{ }^{35} \mathrm{~S}\right]$ cysteine (NEN, Boston, MA). Metabolically labeled cells were incubated with ${ }^{\mathrm{b}} \mathrm{P}-\mathrm{ODN}$ and cross-linked as described above with either DSP, a reversible, membrane impermeable agent, or with its non-cleavable cross-linker equivalent DSS. Cell membranes were then solubilized in NP-40 detergent and ${ }^{\mathrm{b}} \mathrm{P}-\mathrm{ODN}$-binding protein complexes were affinity precipitated with avidin coupled to sepharose (Avidin-Sepharose) as described for immunoprecipitations with monoclonal antibodies (16). The complexes were washed $(2 \times$ in detergent buffer $1 \%$ NP-40 with $0.1 \%$ BSA; $2 \times$ in detergent buffer $0.5 \%$ NP-40; $1 \times$ in detergent buffer $0.1 \%$ NP-40) and eluted from Avidin-Sepharose with SDS-PAGE loading buffer. The proteins were then treated (100 mM DTT, $5^{\prime}$ at $95^{\circ} \mathrm{C}$ ) to cleave the reducible DSP cross-linker and release the ${ }^{b} \mathrm{P}-\mathrm{ODN}$. Proteins were fractionated by SDS-PAGE, the gels dried and subjected to autoradiography to detect ${ }^{\text {b } P-O D N ~ b i n d i n g, ~}$ affinity purified, radiolabeled cell surface proteins.

Binding studies and Scatchard plot analysis were performed as described (16).

K562 cells were also treated with neuraminidase for $1-3 \mathrm{~h}$ to determine the role of glycosylation on the ability of putative binding proteins to interact with P-ODN. Neuraminidase treatment was carried out as previously published (17).
Cell fractionation studies. K562 cells $\left(2 \times 10^{7}\right.$ cells $\left./ \mathrm{ml}\right)$ were exposed to ${ }^{35} \mathrm{~S}$-labeled P-ODN $(2.5 \mu \mathrm{M} ; 2.5 \mu \mathrm{Ci})$ for $1 \mathrm{~h}$ at 4 or $37^{\circ} \mathrm{C}$. Cells were washed in tissue culture medium at $4^{\circ} \mathrm{C}$ to remove free $\mathrm{P}$ ODN, homogenized, and then fractionated by centrifugation. In brief, the washed cell pellet was diluted in $6 \mathrm{ml}$ of hypotonic homogenizing medium (50 mM MOPS, pH 7.4, $1 \mathrm{mM}$ PMSF) and allowed to stand at $4^{\circ} \mathrm{C}$ for $10 \mathrm{~min}$ to swell the cells. Cells thus treated were homogenized with 50 strokes in a glass dounce. The homogenized cell suspension was transferred to a polycarbonate tube, and diluted with $6 \mathrm{ml} 0.5 \mathrm{M}$ sucrose in $50 \mathrm{mM}$ MOPS, pH 7.4, with $1 \mathrm{mM}$ PMSF. The sample was mixed and an aliquot removed for scintillation counting. The remaining material was centrifuged at $50 \mathrm{~g}$ for $5 \mathrm{~min}$ to remove intact cells. The supernatant fraction containing the cell homogenate sub-fractions (S1) was centrifuged again at $1,000 \mathrm{~g}$ for $10 \mathrm{~min}$ to remove nuclei. Radioactivity associated with the isolated nuclei was quantitated using a scintillation counter. The resulting supernatant (S2) was centrifuged at 16,000 $g$ for $20 \mathrm{~min}$ to remove plasma membranes, mitochondria, endosomes, and lysosomes. Radioactivity in the pellet was counted, and the resulting supernatant (S3) was centrifuged again at $160,000 \mathrm{~g}$ for $60 \mathrm{~min}$ to pellet the microsomal fraction containing free ribosomes, and ribosomes associated with rough endoplasmic reticulum. Radioactivity associated with this pellet was also counted, as were counts in the final supernatant (S4) which was the equivalent of free cytosol.

Recovery of P-ODN at each step was compared to total cellular uptake of labeled material under each condition. This was determined by removing a small aliquot of cells immediately after incubation with the labeled P-ODN. The labeled cells were separated from unincorporated counts by sucrose gradient centrifugation. The cell pellet was resuspended in liquid scintillation cocktail in $1 \mathrm{~N} \mathrm{NaOH}$ and counted in a liquid scintillation counter. Protein concentration was determined in each fraction by the method of Lowry et al. (18).

Ultrastructural localization of biotinylated oligodeoxynucleotides in K562 cells. Two different techniques, pre- and post-embedding labeling, were used to ultrastructurally localize cell associated ${ }^{b} \mathrm{P}-\mathrm{ODN}$. Visualization of P-ODN membrane binding protein complexes and the initial internalization process required pre-embedding labeling of bound ${ }^{\mathrm{b}} \mathrm{P}$ ODN because of the low concentrations of the ligand used to demonstrate receptor mediated uptake. In these studies, K562 cells $\left(2 \times 10^{7}\right.$ cells $/ \mathrm{ml}$ ) suspended in RPMI 1640 with $2 \%$ bovine calf serum (GIBCOBRL) were incubated in the presence or absence of $100 \mathrm{nM} \mathrm{c-myb}$ antisense ${ }^{\mathrm{b}} \mathrm{P}-\mathrm{ODN}$ at $4^{\circ} \mathrm{C}$ for $30 \mathrm{~min}$ to saturate putative membrane receptors without allowing internalization. Cells incubated without ${ }^{\mathrm{b}} \mathrm{P}$ ODN were used as controls for labeling specificity. Cells were then washed $2 \times$ and resuspended in PBS $\mathrm{pH} 7.4$. The ${ }^{\text {bP-ODN }}$ were crosslinked to surface binding proteins using the membrane impermeable cross-linker bis ( sulfosuccinimidyl) suberate $\left(\right.$ BS $\left.^{3}\right)(20 \mathrm{mg} / \mathrm{ml}$ ) (Pierce, Rockford, IL). The reaction was quenched by washing the cells $3 \times$ with $50 \mathrm{mM}$ TRIS/HCL in $150 \mathrm{mM} \mathrm{NaCl}$. To label the crosslinked ${ }^{\text {b }} \mathrm{P}$ ODN, cells were incubated at $4^{\circ} \mathrm{C}$ for $1 \mathrm{~h}$ with $10 \mathrm{~nm}$ gold-labeled streptavidin (Zymed Laboratories, Inc., South San Francisco, CA). Thereafter, the cells were warmed to $37^{\circ} \mathrm{C}$ for $20 \mathrm{~min}$ to initiate uptake. The cells were diluted in PBS at $4^{\circ} \mathrm{C}$, centrifuged at $500 \mathrm{~g}$, and the resulting cell pellet fixed overnight in $2 \%$ glutaraldehyde in PBS. The specimens were washed in $0.1 \mathrm{M}$ sodium cacodylate and post-fixed with $2 \% \mathrm{OsO}_{4}$ in $0.1 \mathrm{M}$ sodium cacodylate buffer, $\mathrm{pH} 7.4$, for $1 \mathrm{~h}$ at $4^{\circ} \mathrm{C}$. The cells were stained en bloc with $2 \%$ uranyl acetate, dehydrated with ethanol $(70-100 \%)$ and propylene oxide $(100 \%)$ and embedded in Spurr resin (Electron Microscopy Sciences, Fort Washington, PA). Thin sections were cut, collected on copper grids, and stained with saturated alcoholic uranyl acetate and bismuth subnitrate.

Because studies designed to demonstrate subsequent intracellular processing used a higher ${ }^{\mathrm{b}} \mathrm{P}-\mathrm{ODN}$ concentration and longer incubation times, post-embedding labeling was used to detect the ligand. K562 cells $\left(2.5 \times 10^{7}\right.$ cells $\left./ \mathrm{ml}\right)$ suspended in RPMI 1640 with $2 \%$ bovine calf serum (GIBCO-BRL) were incubated with $10 \mu \mathrm{M}$ c-myb antisense

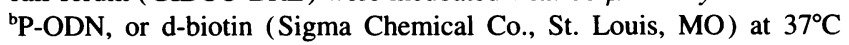
$\left(5 \% \mathrm{CO}_{2}\right)$ for $12 \mathrm{~h}$. The cells were then transferred to Dulbecco's MEM (GIBCO-BRL) and incubated under the same conditions with $5 \mu \mathrm{M}$ ${ }^{b} \mathrm{P}-\mathrm{ODN}$ for an additional $8 \mathrm{~h}$. Cells incubated with d-biotin served as 
a control of labeling specificity of ${ }^{\mathrm{b}} \mathrm{P}-\mathrm{ODN}$, as opposed to endogenous or added biotin, in these experiments. The cells were diluted in PBS at $4^{\circ} \mathrm{C}$, centrifuged at $500 \mathrm{~g}$, and the resulting pellet fixed in $1 \%$ glutaraldehyde, with $0.2 \%$ picric acid in PBS, pH 7.4, overnight at $4^{\circ} \mathrm{C}$. Specimens were dehydrated with ethanol $(70,80$, and $90 \%)$, and embedded in LR White resin (Electron Microscopy Sciences, Ft. Washington, PA.). Thin sections were cut and collected on nickel grids. ${ }^{\text {bP-ODN }}$ were detected by incubating the sections with anti-biotin IgG (Rockland, Inc., Gilbertsville, PA; Sigma Chemical Co.), normal rabbit IgG, or no primary antibody overnight at $4^{\circ} \mathrm{C}$. The sections were washed and incubated with gold-labeled protein A (19) for $1 \mathrm{~h}$ at room temperature. Incubations with normal IgG and no primary antibody served as controls for the specificity of the anti-biotin and gold-labeled protein A labeling. After washing, grids were stained with neutralized uranyl acetate.

All sections were observed and photographed in a JEOL 100CX transmission electron microscope.

Nuclear import of fluorescent $O D N$. Proliferating cells from the melanoma cell line HS $294 \mathrm{~T}$ were plated at subconfluency in 96-well plates, or on glass slides with cell culture chambers attached via a removable gasket (Lab-Tek, Nunc, Naperville, Il). After 48 h growth, cells were washed with ice cold transport buffer (TB). Cell membranes were selectively permeablized by exposure to $40 \mu \mathrm{g} / \mathrm{ml}$ digitonin (Sigma Chemical Co.) in TB for $5 \mathrm{~min}$. The permeabilized cells were incubated for $30 \mathrm{~min}$ at $4^{\circ} \mathrm{C}$ with either anti-vimentin mouse IgG (Sigma Chemical Co.) or anti-PCNA mouse IgG (Boehringer-Mannheim, Indianapolis, IN) diluted 1:160 and 1:80 in TB, respectively. The cells were washed $2 \times$ with ice-cold TB, and then incubated with $2 \%$ sheep serum in $\mathrm{TB}$ for $10 \mathrm{~min}$ at $4^{\circ} \mathrm{C}$ to reduce nonspecific signal. Cells were then incubated for $30 \mathrm{~min}$ at $4^{\circ} \mathrm{C}$ with FITC labeled rabbit anti-mouse IgG in a 1:128 dilution with TB and 2\% sheep serum. Cells were analyzed by phase contrast and epifluorescence.

To ensure that PCNA could be detected in permeabilized nuclei, melanoma cells were also fixed in $1 \%$ paraformaldehyde for $2 \mathrm{~min}$ at room temperature and then permeabilized with methanol for $10 \mathrm{~min}$ at $-20^{\circ} \mathrm{C}$. The cells were then incubated with anti-PCNA antibody followed by washing with $0.1 \%$ Triton in TB. The cell preparations were then incubated with the appropriate fluorescein labeled second antibody and examined with a fluorescence microscope.

To analyze nuclear import of ODN, digitonin-permeabilized cells were incubated for $30 \mathrm{~min}$ at room temperature with transport medium (TM) containing $60 \%$ ( $\mathrm{vol} / \mathrm{vol}$ ) dialyzed rabbit reticulocyte lysate in TB, $3.3 \mu \mathrm{M}$ FITC-tagged c-my $b$ antisense P-ODN, $20 \mathrm{mM}$ Hepes, $\mathrm{pH}$ 7.3, $110 \mathrm{mM}$ potassium acetate, $5 \mathrm{mM}$ sodium acetate, $2 \mathrm{mM}$ DTT, $1.0 \mathrm{mM}$ EGTA, $1.0 \mathrm{mM}$ ATP (Sigma Chemical Co.), $5 \mathrm{mM}$ creatine phosphate (Sigma Chemical Co.), $20 \mathrm{U} / \mathrm{ml}$ creatine phosphokinase (Sigma Chemical Co.) and $1 \mu \mathrm{g} / \mathrm{ml}$ each aprotinine, leupeptin and pepstatin. Rabbit reticulocyte lysate (Promega, Madison, Wisconsin) was prepared for use by centrifugation at $100,000 \mathrm{~g}$. The supernatant obtained was dialyzed against transport buffer (20 mM HEPES, pH 7.3, $110 \mathrm{mM}$ potassium acetate, $5 \mathrm{mM}$ sodium acetate, $2 \mathrm{mM}$ magnesium acetate, $1 \mathrm{mM}$ EGTA, $2 \mathrm{mM}$ DTT, $1 \mu \mathrm{g} / \mathrm{ml}$ aprotinin, $1 \mu \mathrm{g} / \mathrm{ml}$ leupeptin and $1 \mu \mathrm{g} / \mathrm{ml}$ pepstatin) in tubing (Spectrum Medical Industries, Los Angeles, CA) with a molecular weight cut-off of $12,000-14,000$. Aliquots were frozen in liquid nitrogen and stored at $-80^{\circ} \mathrm{C}$.

To investigate the effect of lectins on nuclear import of P-ODN, permeabilized cells were pre-incubated ( 20 minutes at room temperature) with either wheat germ agglutinin (WGA; Sigma Chemical Co.) or concanavalin A (Con A; Sigma Chemical Co.) (each $100 \mu \mathrm{g} / \mathrm{ml}$ in TM). Cells were then incubated for $30 \mathrm{~min}$ at room temperature with transport medium containing $3.3 \mu \mathrm{M}$ of fluorescein tagged c-myb antisense P-ODN. After washing with TM, the cells were analyzed by phase contrast and epifluorescence.

\section{Results}

P-ODN uptake mechanisms are concentration dependent. It remains uncertain if P-ODN gain entrance to cells by fluidphase endocytosis, "receptor"-mediated endocytosis, or by

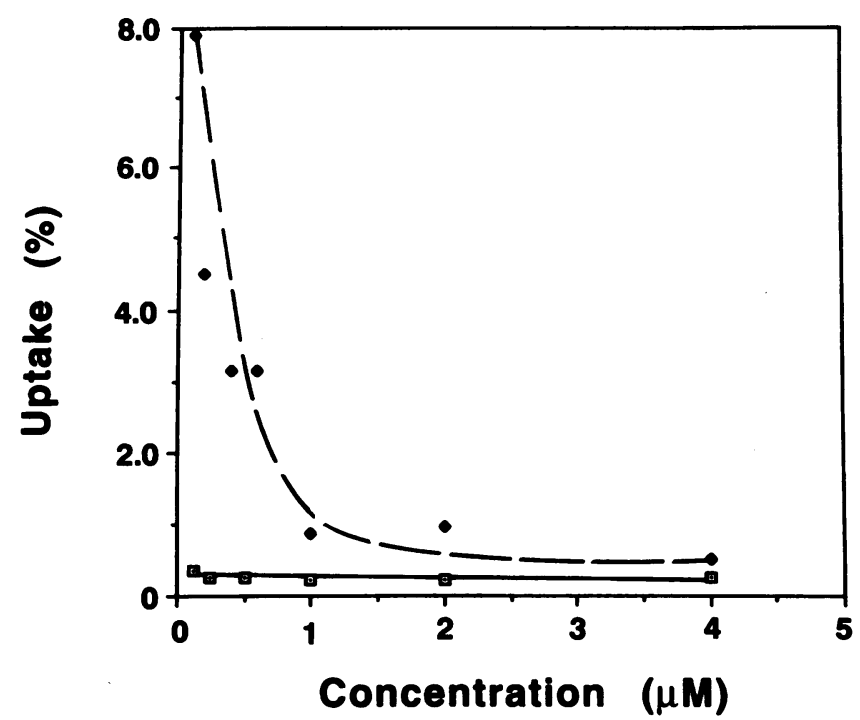

Figure 1. P-ODN uptake mechanisms are concentration dependent. $\mathrm{K} 562$ cells $\left(2 \times 10^{7} / \mathrm{ml}\right)$ were incubated for $6 \mathrm{~h}$ at $37^{\circ} \mathrm{C}$ with varying concentrations of either ${ }^{14} \mathrm{C}$-sucrose (solid line) or ${ }^{35} \mathrm{~S}$-labeled P-ODN (dashed line). After incubation, cells were washed $3 \times$ in PBS. Radioactivity in the wash supernatant and lysed pellet was measured and expressed as a ratio (\% uptake) on the y-axis. Percent uptake of ${ }^{14} \mathrm{C}$ sucrose remained constant with varying extracellular concentration whereas percent uptake of ${ }^{35} \mathrm{~S}$-labeled P-ODN decreased as the extracellular concentration increased.

some combination of both processes. We addressed this issue in a formal manner by directly comparing uptake of ${ }^{35} \mathrm{~S}$-labeled P-ODN with uptake of ${ }^{14} \mathrm{C}$-sucrose, a molecule which is transported into cells exclusively by fluid phase endocytosis (20). We found that both mechanisms are active (Fig. 1). At P-ODN concentrations $>1 \mu \mathrm{M}$ uptake of material paralleled uptake of ${ }^{14} \mathrm{C}$-sucrose. For both compounds, total uptake increased in a linear fashion with increasing extracellular concentrations, while the percentage of material entering the cells remained constant. This pattern is consistent with fluid phase endocytosis. However, as extracellular concentrations decreased below $1 \mu \mathrm{M}$ the efficiency of uptake of ${ }^{35} \mathrm{~S}$-labeled P-ODN greatly exceeded that of the ${ }^{14} \mathrm{C}$-sucrose (Fig. 1). This pattern is consistent with receptor mediated uptake, a process which becomes increasingly effective with decreasing extracellular concentrations. Accordingly, two different mechanisms for importing P-ODN appear active in the cells examined, and the mechanism utilized appeared to be dependent on the extracellular concentration of DNA. The existence of a receptor-like uptake mechanism implied the existence of proteins which specifically bound the PODN. Accordingly, we sought to identify these receptor-like oligonucleotide cell surface binding proteins.

$P$-ODN bind specifically to numerous cell membrane proteins. $\mathrm{K} 562$ cells were incubated with ${ }^{\mathrm{b}} \mathrm{P}-\mathrm{ODN}$ at $4^{\circ} \mathrm{C}$ as described and then cross-linked with $\mathrm{BS}^{3}$ to the membrane proteins to which they had bound. After cross-linking, the membranes were solubilized, and the protein- ${ }^{\mathrm{b}} \mathrm{P}-\mathrm{ODN}$ complexes separated by PAGE under denaturing conditions. Material in the gel was transferred to PVDF membranes, Western blotted with Avidin-HRP and detected colorimetrically using enhanced chemiluminescence. Five major doublet bands were seen at $137-147 \mathrm{kD}, 79-85 \mathrm{kD}, 43-46 \mathrm{kD}, 29-32 \mathrm{kD}$, and 20-22 $\mathrm{kD}$ (Fig. 2). Other minor bands between these weight ranges 


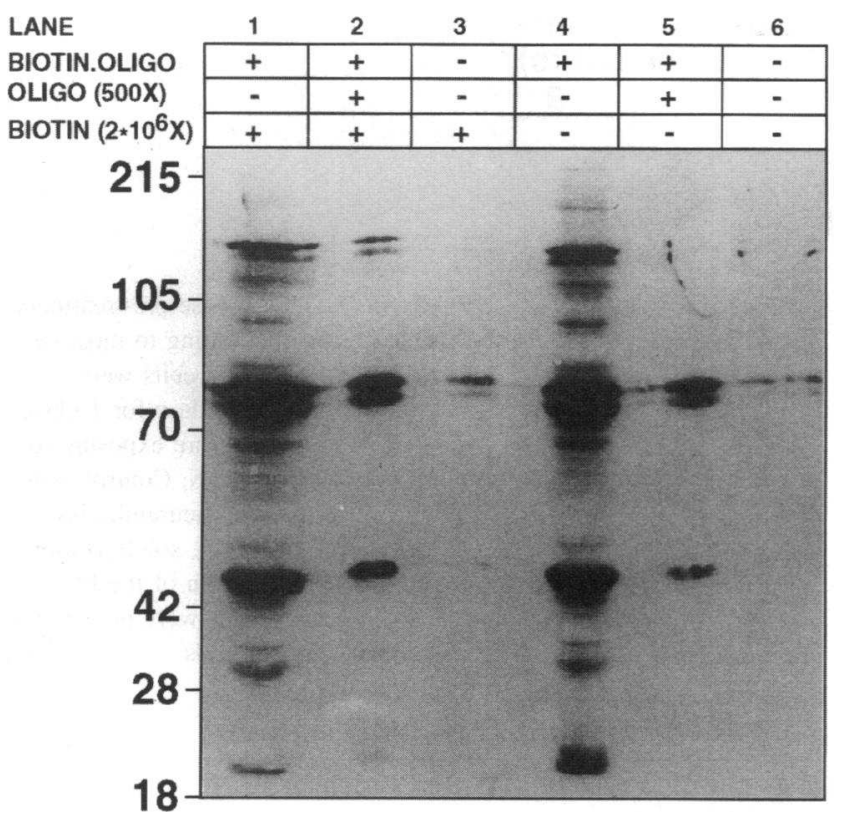

Figure 2. Cross linking studies demonstrate that P-ODN bind specifically to numerous cell membrane proteins. As described in the methods section, $\mathrm{K} 562$ cells were incubated at $4^{\circ} \mathrm{C}$ with c-myb antisense ${ }^{\mathrm{b}} \mathrm{P}$ ODNs and excess d-biotin (lane 1); with c-myb antisense ${ }^{\text {bP-ODN, a }}$ 500 -fold excess of unbiotinylated c-myb antisense P-ODN, and excess d-biotin (lane 2); d-biotin alone (lane 3); c-myb antisense bP-ODN alone (lane 4); c-myb antisense ${ }^{b}$ P-ODN and a 500 -fold excess of unbiotinylated c-myb antisense P-ODN (lane 5); or with culture medium alone (lane 6). Crosslinking was carried out with $\mathrm{BS}^{3}(2 \mathrm{mM})$, the cells were washed $\left(4^{\circ} \mathrm{C}\right)$, and membrane proteins solubilized with $2 \%$ NP-40. The proteins were separated by SDS-PAGE, transferred to nitrocellulose or PVDF membranes by Western blotting, and detected with Avidin-Horseradish Peroxidase and the Enhanced Chemoluminescence Kit (BRL). Molecular size markers are indicated on the left side of the figure.

were seen as well. Identical data were obtained when DSS was used as the cross-linker (data not shown).

The specificity of the cross-linking of surface proteins and ${ }^{b} \mathrm{P}-\mathrm{ODN}$ was determined by the following two sets of experiments. First, binding studies were carried out in the presence of a 500-fold excess of nonbiotinylated DNA competitor. Crosslinking was then performed as described. As seen in Fig. 2, lane 5 binding of ${ }^{b} \mathrm{P}-\mathrm{ODN}$ was totally inhibited by the presence of unbiotinylated P-ODN, except for fainter bands in the range of $79-85 \mathrm{kD}$ and $43-46 \mathrm{kD}$. Even in this group however, binding appeared to be significantly diminished. Second, we excluded the possibility that the material binding to cell surface proteins was the biotin moiety of ${ }^{\mathrm{b}} \mathrm{P}-\mathrm{ODN}$ rather than the ODN. This was done by examining the ability of d-biotin to bind to surface proteins, and by examining the ability of d-biotin to competitively inhibit binding of the ${ }^{b} P-O D N$. We found that $d-$ biotin by itself bound only weakly to a protein of $\sim 85 \mathrm{kD}$ (fig. 2 , lane 3 ). We also found that in the presence of a vast excess $\left(2 \times 10^{6}\right.$ fold ) of d-Biotin, the intensity of the bands to which the ${ }^{b} \mathrm{P}-\mathrm{ODN}$ bound remained unchanged except for the band at $\sim 22 \mathrm{kD}$, which disappeared (Fig. 2, lane 1). Finally, we demonstrated that in the presence of excess of both d-biotin and P-ODN the bands remaining, if any, were identical to those observed in the presence of competing P-ODN alone (Fig. 2, lane 2). Therefore, except for the protein at $22 \mathrm{kD}, \mathrm{P}-\mathrm{ODN}$

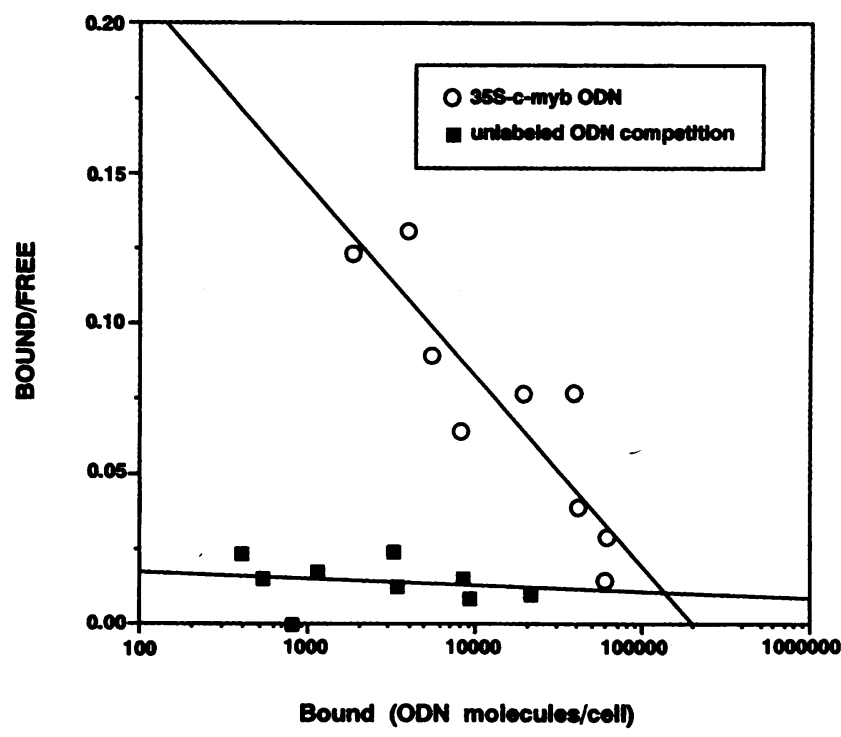

Figure 3. Scatchard plot analysis of P-ODN cell surface binding proteins on K562 cells. Binding studies were performed as described (15). Briefly, $1 \times 10^{6}$ intact K562 cells were incubated with serial dilutions of ${ }^{35}$ S-labeled P-ODN ( $1 \mu \mathrm{Ci} / \mu \mathrm{g}, 2 \times 10^{6} \mathrm{dpm}$, in $100 \mu \mathrm{l}$ binding buffer [PBS plus $0.1 \%$ BSA]) in the absence (open circles) or presence (filled squares) of 500 -fold excess of unlabeled P-ODN competitor. After washing, cell associated (bound) and soluble (free) material was collected and the counts were determined. Results were plotted and subjected to Scatchard Analysis. Representative ${ }^{35}$ S-labeled P-ODN binding plots in the absence (open circles), or in the presence of a 500fold excess of unlabeled ODN (closed squares) are shown.

were shown to bind specifically to a large number of cell surface proteins.

Quantitation of P-ODN binding sites on K562 cells. We next sought to determine the actual number of P-ODN binding sites on the surface of K562 cells. Binding studies and Scatchard plot analysis were performed as described (16). $1 \times 10^{6}$ intact K562 cells were incubated with serial dilutions of ${ }^{35} \mathrm{~S}$-labeled P-ODN $\left(1 \mu \mathrm{Ci} / \mu \mathrm{g}, 2 \times 10^{6} \mathrm{dpm}\right)$ in the presence or absence of 100-fold excess of unlabeled P-ODN competitor. After washing, cell associated (bound) and soluble (free) material was collected and the counts were determined. Results were plotted and subjected to Scatchard Analysis (Fig. 3). The analysis suggested that the binding proteins, though numerous, were of a single binding affinity. The average affinity detected from 4 independent experiments was of $3.5 \pm 2.2 \mu \mathrm{M}$, and there appeared to be approximately 200,000 binding sites/cell on the surface. All binding sites were competed by the addition of unlabeled P-ODN, suggesting that the putative receptors are indeed specific for P-ODN (Fig. 3). Similar studies were carried out with two other leukemic cell lines, Jurkatt and EL-4. Though receptor density varied on these lines (from 2-5-fold in comparison to K562) P-ODN receptor affinity was not significantly different (HUS, data not shown). Finally, we also examined binding of higher molecular weight native DNA fragments $(\lambda$ digest, $1-12 \mathrm{kB}$ ) to determine if larger DNA fragments were bound to cells by a different class of proteins. We found however that the apparent number and affinity of receptors for high molecular weight DNA fragments was indistinguishable from those which bound the P-ODN (HUS, data not shown).

Direct detection and partial characterization of $P$-ODN binding proteins. The results described above indicated that at 


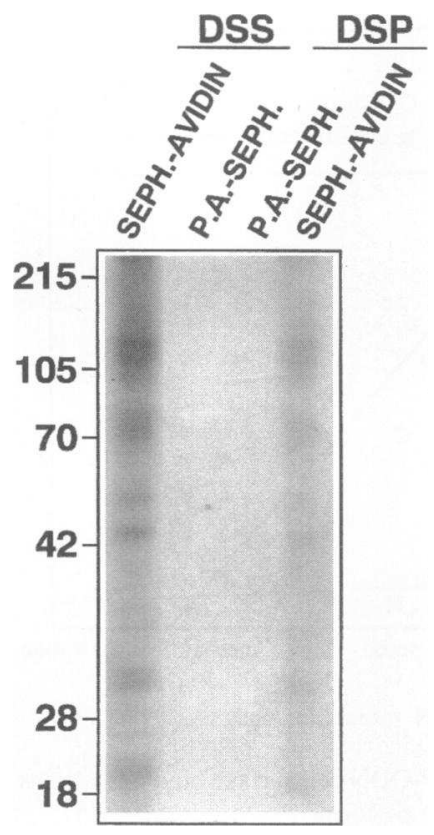

Figure 4. Direct analysis of metabolically labeled ${ }^{\mathrm{P}} \mathrm{P}-\mathrm{ODN}$ binding proteins. K562 cells metabolically labeled with $\left[{ }^{35} \mathrm{~S}\right]$ methionine and $\left[{ }^{35} \mathrm{~S}\right]$ Cysteine. The metabolically labeled cells were then incubated with ${ }^{\mathrm{b}} \mathrm{P}$ ODN as detailed in the methods. Cross-linking of ${ }^{\mathrm{b}} \mathrm{P}-\mathrm{ODN}$ and their binding proteins was carried out with either noncleavable $(D S S)$ or cleavable (DSP) agents as detailed in the methods. Cell membranes were solubilized and ${ }^{b} \mathrm{P}-\mathrm{ODN} / \mathrm{binding}$ protein complexes were precipitated with Avidin-Sepharose. Complexes eluted from the Avidin-Sepharose matrix were resolved by SDS-PAGE. 'P-ODN binding, affinity purified, radiolabeled cellular proteins were then detected by autoradiography. As shown here, the binding protein patterns did not differ

with either cross-linker suggesting that P-ODN bound to individual proteins, and the receptors did not oligomerize upon binding of the P-ODN.

least five major groups of cell surface proteins specifically bound the P-ODN. However, it was uncertain from the data whether these were individual proteins. It was possible for example that upon binding of the ODN, the binding proteins dimerize or oligomerize. Such complexes would then be crosslinked together giving the complex banding pattern observed in Fig. 2. To investigate this possibility, we metabolically labeled the P-ODN binding proteins and then carried out binding experiments with non-reducible and reducible cross-linking agents. We reasoned that if reduction of the crosslinks after solubilization of surface proteins led to a change in electrophoretic band patterns of solubilized surface proteins, formation of binding protein complexes was likely.

$\mathrm{K} 562$ cells were metabolically labeled with [ ${ }^{35} \mathrm{~S}$ ] methionine and $\left[{ }^{35} \mathrm{~S}\right]$ cysteine after which they were then incubated with ${ }^{b}$ P-ODN. Crosslinking was then carried out with either DSS or DSP. The ODN-binding protein complexes were solubilized, and then isolated by affinity precipitation with Avidin-Sepharose. After isolation, complexes formed with DSP were dissociated by cleavage of the crosslinker by subjecting it to DTT reduction. Proteins obtained by both cross-linking methods were resolved by SDS-PAGE and bands were detected by autoradiography. The intensity of bands detected by this method of labeling was clearly less than obtained by cross-linking to the ${ }^{\mathrm{b}} \mathrm{P}$ ODN. Nevertheless, we were still able to demonstrate that the size and number of P-ODN PBs was identical regardless of whether the non-cleavable or cleavable cross-linker was used (Fig. 4). Accordingly, the bands resolved in Fig. 2 likely represent individual proteins. It also follows that oligomerization of receptors is unlikely to take place upon binding of the P-ODN. Specificity of the precipitations were demonstrated by showing that protein $\mathrm{A}$-sepharose by itself was unable to precipitate any material.

Role of sialic acid moieties in P-ODN binding. The number and diversity of proteins to which the P-ODN had bound sug-

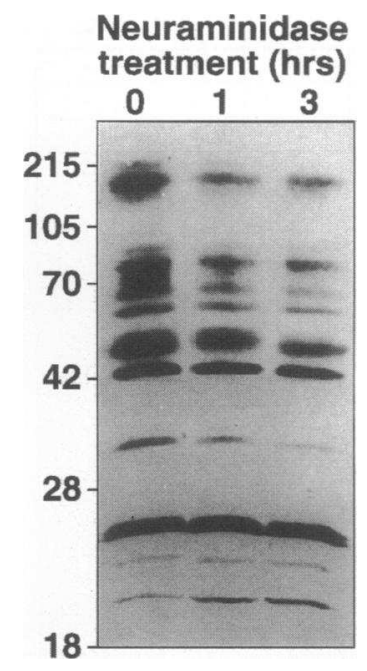

Figure 5. Neuraminidase pre-treatment decreases P-ODN binding to most cell surface proteins. K562 cells were treated with neuraminidase for 1 (lane 1) or 3 (lane 3 ) h before exposure to $c-m y b$ antisense P-ODN. Control cells were not treated with neuraminidase (lane 0 ). Cross-linking, solubilization, separation and detection of the PSODN binding proteins were performed as described in Methods. gested that the interactions detected may have been of ionic nature, due to the negative charge of the DNA. Further experiments were conducted to investigate this possibility and to determine the effect of cell surface charge on P-ODN binding. To address this issue, K562 cells were treated with neuraminidase for 1 to $3 \mathrm{~h}$ to remove sialic acid residues prior to incubation and crosslinking with ${ }^{\mathrm{b}} \mathrm{P}-\mathrm{ODN}$. We expected that if charge played a significant role in P-ODN binding, removal of negatively charged sialic acid residues would result in increased apparent P-ODN binding. As shown in Fig. 5 however, treatment with neuraminidase decreased binding to proteins $\sim 43 \mathrm{kD}$, and to a lower molecular weight species $(\sim 34 \mathrm{kD})$ as well. In these proteins then, glycosylation state clearly plays a role in the ability of the binding proteins to interact with the P-ODN. Other proteins, in particular those in the $\sim 42$ and $\sim 24 \mathrm{kD}$ groups, showed no apparent change in binding ability after treatment with neuraminidase suggesting that glycosylation of the putative receptors was of less importance for binding. Only one species manifested an apparent binding increase after removal of sialic acid residues $(\sim 20 \mathrm{kD})$ suggesting that this interaction was primarily charge mediated.

Visualization of P-ODN uptake and intracellular trafficking. The data presented above suggested that P-ODN were taken into cells by fluid phase endocytosis and by receptor-mediated endocytosis. The latter mechanism would predict the existence of proteins which specifically bound the P-ODN, and this was ultimately verified. We then undertook experiments to directly visualize the uptake process and to track the P-ODN once they had entered the cell (Fig. 6). Endocytosis is accomplished in many cells by the formation of coated pits and vesicles. Accordingly, we would predict that labeled material would be detected within such structures. Using a pre-embedding technique and gold-tagged ${ }^{\mathrm{b}} \mathrm{P}-\mathrm{ODN}$ we were able to directly visualize oligodeoxynucleotides within clathrin coated pits on the cell surface of K562 cells (Fig. $6 \mathrm{~A}$ ). To track internalized oligodeoxynucleotides, we used a post-embedding technique and were able to show P-ODN within clear vesicles. Such structures are likely coated vesicles which have lost their clathrin coat, consistent with transport within endosomes (Fig. $6 \mathrm{~B}$ ). Besides being located within or at the periphery of endosomes, P-ODN can be seen within dense, lysosome-like structures (Fig. $6 \mathrm{C}$ ). In other sections, P-ODN were also visualized free within the cytoplasm and within the nucleus. In the latter structure they prefer- 

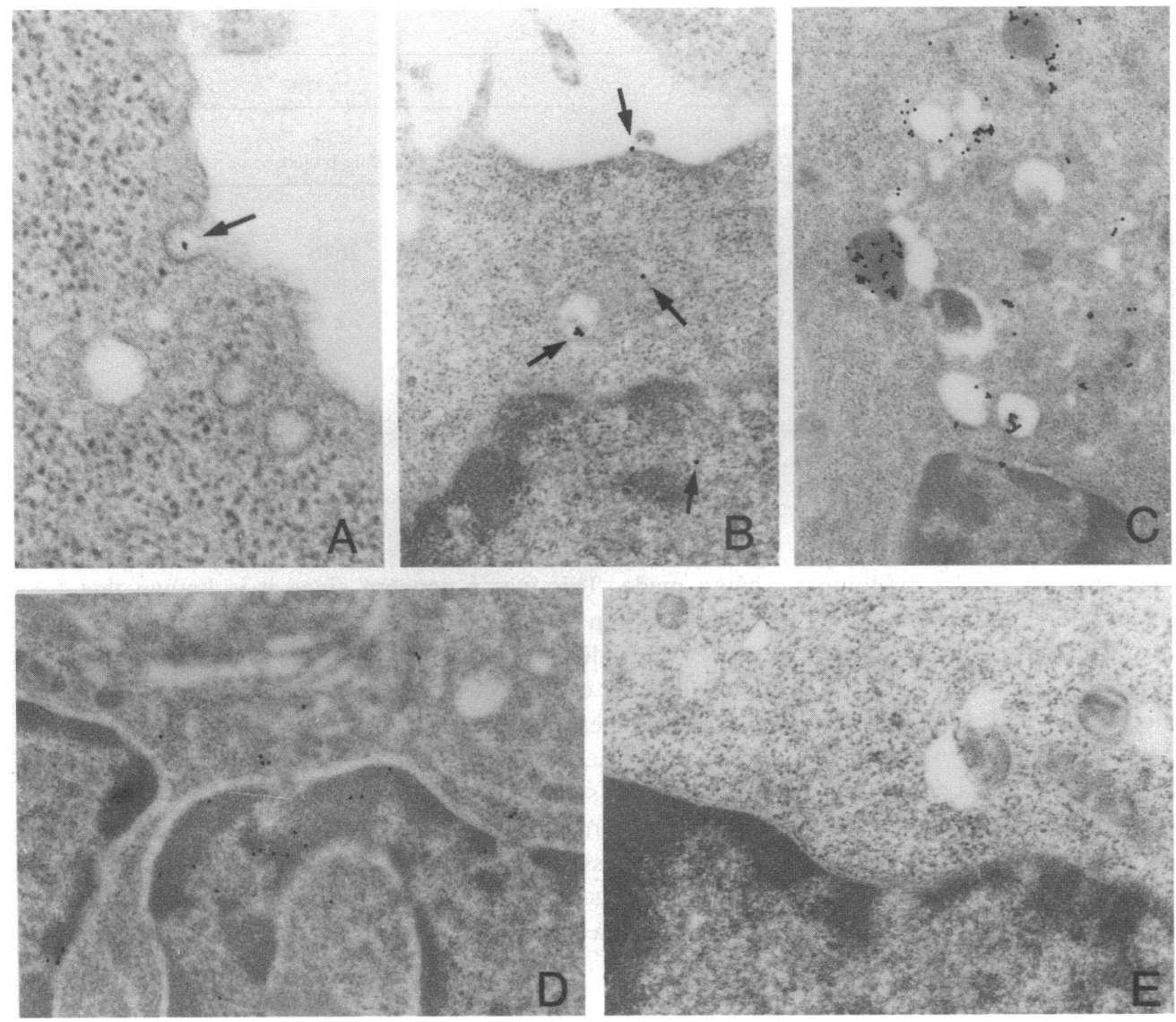

Figure 6. Visualization of P-ODN uptake and intracellular trafficking by electron microscopy. Electron photomicrographs of ${ }^{\mathrm{P}} \mathrm{P}-\mathrm{QDN}$ in a clathrin coated pit $(A)$; within endosomes (clear vesicles) $(B)$; in lysosome-like structures (dark vesicles) $(C)$; and free within the cytoplasm, and at the euchromatin/heterchromatin interface $(D)$ No gold particles were observed in cells incubated in free biotin alone $(E)$.

entially localized to the euchromatin/heterochromatin interface (Fig. 6D). Cells incubated with avidin-gold in the absence of ${ }^{b} \mathrm{P}-\mathrm{ODN}$ showed only a few, randomly distributed gold particles (Fig. $6 E$ ).

We were also very interested in knowing if labeled P-ODN could be detected in the endoplasmic reticulum or in association with ribosomes. Since it has been suggested that ODN may perturb gene function by hybridizing with mRNA and preventing ribosomal translation, such an association might reasonably be expected. Nevertheless, an extensive search of the ultrastructural data available failed to reveal an association between these structures and the labeled P-ODN. To substantiate the observation that P-ODN do not associate appreciably with ribosomes or endoplasmic reticulum, cell fractionation studies were carried out after incubating K562 cells with ${ }^{35} \mathrm{~S}$-labeled P-ODN. As shown in Table I, the major site of P-ODN accumulation was the nucleus. The specific activity of P-ODN binding to the nuclear fraction was $3740 \mathrm{pmole} / \mathrm{mg}$ of protein $(\sim 50 \%$ of total ) after $60 \mathrm{~min}$ incubation at $37^{\circ} \mathrm{C}$. The only other significant site of P-ODN accumulation was the plasma membrane where $755 \mathrm{pmole} / \mathrm{mg}$ of protein was detected. In contrast, 92 pmole/ $\mathrm{mg}$ protein accumulated in the microsomal fraction containing the ribosomes. The latter value represented $\sim 2 \%$ of the nuclear specific activity and could not be reliably distinguished from background counts. It is therefore unlikely that there is a significant association between P-ODN and mRNA translational machinery in the cytoplasm.

Mechanism of nuclear import of $P-O D N$. To investigate the mechanism of nuclear import of P-ODN we established a system similar to those utilized to study nuclear import of proteins. This system employs an agent, digitonin, which selectively per- meabilizes the cell's cytoplasmic membrane while leaving the cytoskeleton and the nucleus intact. When incubated in the appropriate medium, cells remain viable for several hours. It is therefore preferable to systems which utilize physical isolation techniques since they invariably result in damage to the nucleus and supporting structure.

To test this system, HS 294 T melanoma cells were cultured for $48 \mathrm{~h}$, permeabilized with digitonin, and then incubated with either anti-vimentin mouse IgG or anti-PCNA mouse IgG as described in the methods. After washing, and addition of FITC labeled rabbit anti-mouse IgG, the cells were analyzed by phase contrast and fluorescence. In the majority of digitonin-treated HS $294 \mathrm{~T}$ cells the cell membrane became permeabilized to molecules the size of IgG as demonstrated by the detection of the cytoskeletal protein vimentin with anti-vimentin (Fig. 7, A and $B$ ). Integrity of the nuclear envelope in the digitonin-treated cells was demonstrated by showing that, in the absence of nuclear permeabilizing agents, incubating cells with an anti-PCNA antibody produced no fluorescence signal (Fig. 7, $C$ and $D$ ). In contrast, following permeabilization of the nuclear envelope with methanol and triton, the same antibody gave easily detectable signal in the nucleus of the cells (Fig. 7, $E$ and $F$ ). Since this system performed as expected, we then utilized it to examine potential nuclear uptake mechanisms of P-ODN.

To determine whether P-ODN uptake used nuclear pore transport mechanisms similar to those employed for transport of larger proteins, $t-R N A s$, and snRNPs we investigated whether nuclear import could be blocked by either wheat germ agglutinin (WGA) or concanavalin A (Con A). Digitonin-treated HS $294 \mathrm{~T}$ cells were first exposed to fluorescein labeled P-ODN. In the absence of cytoplasmic and nuclear permeabilization, no 
Table I. Cellular Distribution of ${ }^{35}$ S-labeled P-ODN

\begin{tabular}{|c|c|c|c|c|c|c|}
\hline \multirow[b]{2}{*}{ Cell fraction } & \multicolumn{3}{|c|}{$4^{\circ} \mathrm{C}$} & \multicolumn{3}{|c|}{$37^{\circ} \mathrm{C}$} \\
\hline & Raw cpm & $\mathrm{cpm} / \mathrm{mg}$ protein & $\begin{array}{c}\text { Specific activity } \\
\text { (pmole/mg protein) }\end{array}$ & Raw cpm & $\mathrm{cpm} / \mathrm{mg}$ protein & $\begin{array}{c}\text { Specific activity } \\
\text { (pmole/mg protein) }\end{array}$ \\
\hline Intact cells & 69,533 & $\amalg^{*}$ & - & 100,065 & - & - \\
\hline Cell homogenate & 68,473 & 1984 & 456 & 97,164 & 2646 & 604 \\
\hline Nuclei & 9410 & 3361 & 773 & 47,165 & 16,263 & 3740 \\
\hline Plasma membrane & 23,644 & 3422 & 787 & 26,424 & 3295 & 750 \\
\hline Microsomal fraction & 1718 & 359 & 82 & 1849 & 402 & 92 \\
\hline Free cytosol & 26,634 & 1692 & 389 & 21,041 & 1312 & 302 \\
\hline
\end{tabular}

* Not determined.

labeled ODN was detectable in the nucleus of the digitonin treated cells (Fig. 8, $A$ and $B$ ). Nuclear fluorescence was clearly visible however after treating cells with digitonin and triton indicating that the labeled P-ODN could enter the nuclei (Fig. $8, C$ and $D$ ). When digitonin treated cells were exposed to the fluorescein labeled P-ODN after pre-treating cells with either WGA (Fig. 8, $E$ and $F$ ) or CON-A (Fig. 8, $G$ and $H$ ) nuclear fluorescence was clearly seen. These experiments suggest that nuclear uptake of the P-ODN does not rely on nucleoporins since transport dependent on these proteins is consistently blocked by lectins like WGA and Con-A.

\section{Discussion}

It was once assumed that highly charged DNA molecules could not be transported across cell membranes. This widely held belief has now been shown to be erroneous, as many laboratories have provided evidence that DNA molecules, of both low and high molecular weight, can associate with cell surfaces and become internalized (21-26). There has been recent speculation that the ability to internalize DNA may represent a salvage pathway for material excreted by apoptotic cells (27), however the physiologic significance of DNA import remains uncertain. Equally uncertain is the mechanism whereby these molecules are taken into cells. Renewed interest in this subject has been prompted by reports that uptake of naked DNA may provide a vehicle for delivery of some forms of gene therapy $(1,10,11)$. Accordingly, we sought to better define both uptake mechanisms and intracellular trafficking of phosphorothioate modified DNA molecules since these are presently being evaluated in a number of clinical settings.

In contrast to earlier studies, we simultaneously employed both biochemical and ultrastructure visualization techniques. We also used P-ODN that had been labeled with biotin, a molecule not previously utilized for this purpose. We labeled the PODN with biotin for several reasons. First, the N-groups in the uriedo ring of the biotin-moiety enabled the formation of stable cross-links between the P-ODN and the proteins to which they had bound. Second, the biotin moiety also permitted sensitive, specific, and rapid colorimetric detection of the P-ODN binding proteins complexes. Lastly, the biotin molecule provided a means of visualizing P-ODN binding, internalization, and intracellular trafficking at the ultrastructural level by electron microscopy using streptavidin-gold particles. The validity of this approach was of course dependent on demonstrating that the biotin moiety itself was not contributing to the observations being made. This was a concern since it is known that free biotin is taken up by some cells in a concentration (28) and energy dependent manner (29). It is also known that complexing biotin to other molecules, for example avidin (29-31), can also influence the uptake of this molecule. We effectively excluded these concerns however by demonstrating that free biotin alone, save for weak binding to an $\sim 85 \mathrm{kD}$ protein, could not be cross-linked to cell surface proteins, that free biotin in large excess did not substantially alter the binding of ${ }^{\mathrm{b}} \mathrm{P}$ ODN to surface proteins (Fig. 2), and that biotin molecules existent within cells were not significantly labeled by the avidingold particles used to detect the ${ }^{\text {bP-ODN by EM. }}$

At present, controversy exists as to whether uptake of PODN relies on fluid phase endocytosis, receptor mediated endocytosis, or both. Evidence supporting each of these mechanisms has recently been reviewed by Bennet (27). In essence however, it has been shown that uptake of either native or modified ODN molecules is saturable, subject to competition, and is energy and temperature dependent $(26,32)$. Energy and temperature dependence indicate only that the process is active, since either fluid phase endocytosis and receptor mediated endocytosis will both be effected by changes in these parameters. That ODN uptake is saturable, and subject to specific competitive inhibition suggests a receptor mediated process, but evidence indicating that ODN are taken up by a protein kinase $\mathrm{C}$-dependent pinocytotic mechanism has also been provided (25). Our studies appear to resolve some of these issues by demonstrating that below a concentration of $1 \mu \mathrm{M}, \mathrm{P}-\mathrm{ODN}$ uptake is predominantly via a receptor-like mechanism while at higher concentrations, a fluid phase endocytosis mechanism appears to predominate. These studies therefore support earlier work which suggested that ODN uptake mechanisms are likely to vary with extracellular concentration (21) and extend them by providing the first direct physical evidence that ODN may be found within clathrin coated pits on the cytoplasmic membrane.

The presence of P-ODN in clathrin coated pits per se does not distinguish between a fluid phase or a receptor-like endocytotic import mechanisms. Nevertheless, we believe that we have visualized the latter for several reasons. First, P-ODN binding was carried out at $4^{\circ} \mathrm{C}$. The cells were then washed at this temperature prior to cross linking the membrane bound material. Given the low affinity nature of the P-ODN binding protein interactions, it is unlikely that significant material would have remained associated with the membrane for endocytosis to occur when the cells were subsequently warmed to $37^{\circ} \mathrm{C}$. Second, the competition and binding experiments also indicate the pres- 

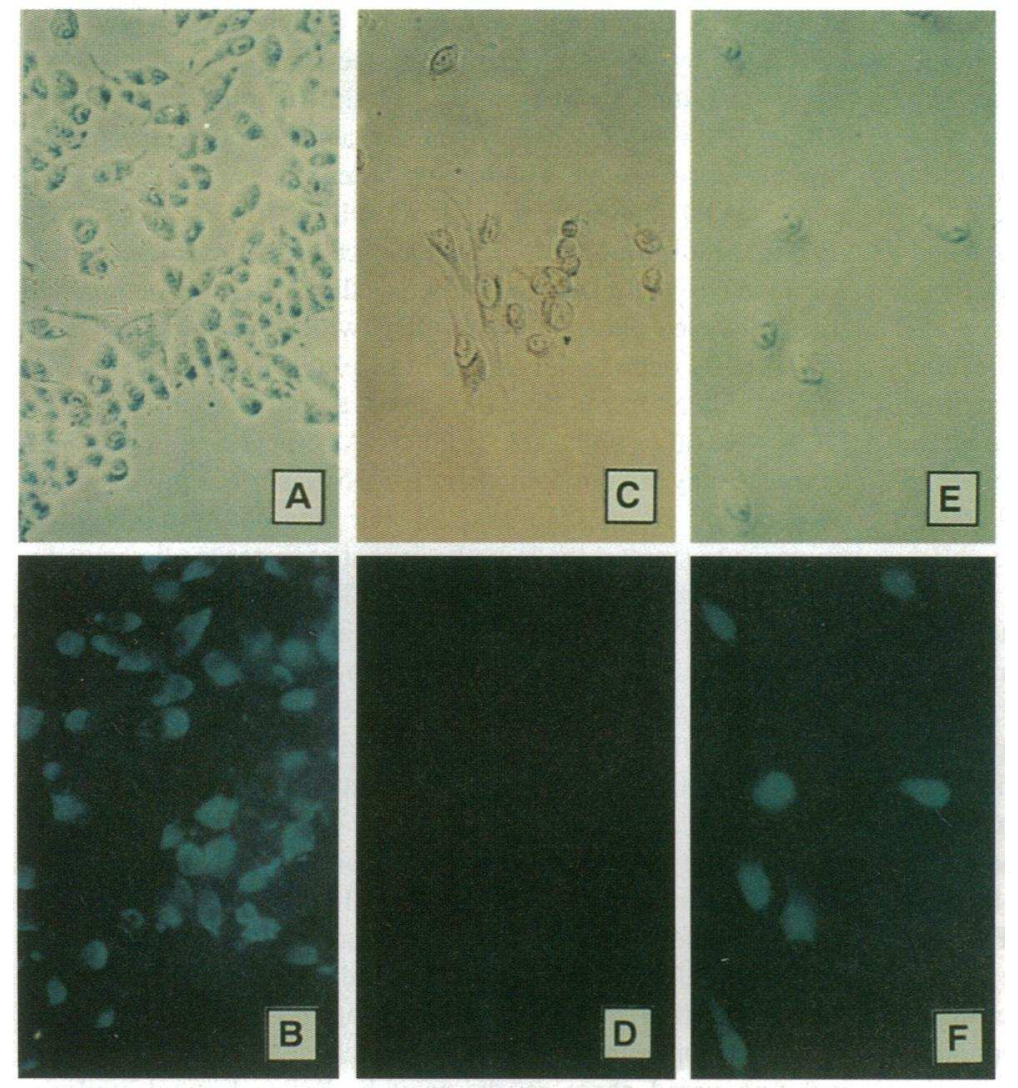

Figure 7. Digitonin treatment of HS 294 T melanoma cells permeabilizes the cell membrane while keeping the nuclear envelope intact. HS $294 \mathrm{~T}$ cells were permeabilized with digitonin and then incubated with either anti-vimentin mouse IgG ( $A$ and $B$ ) or anti-PCNA mouse IgG ( $C$ and $D$ ) followed by incubation in fluorescein labeled rabbit antimouse IgG. Cells were analyzed by phase contrast ( $A$ and $C)$ and epifluorescence $(B$ and $D)$. As a positive control for the anti-PCNA label, cells were fixed in 1\% paraformaldehyde, methanol permeabilized, incubated with antiPCNA, washed, and then incubated with fluorescein conjugated anti-mouse IgG (E-phase contrast; F-epifluorescence).
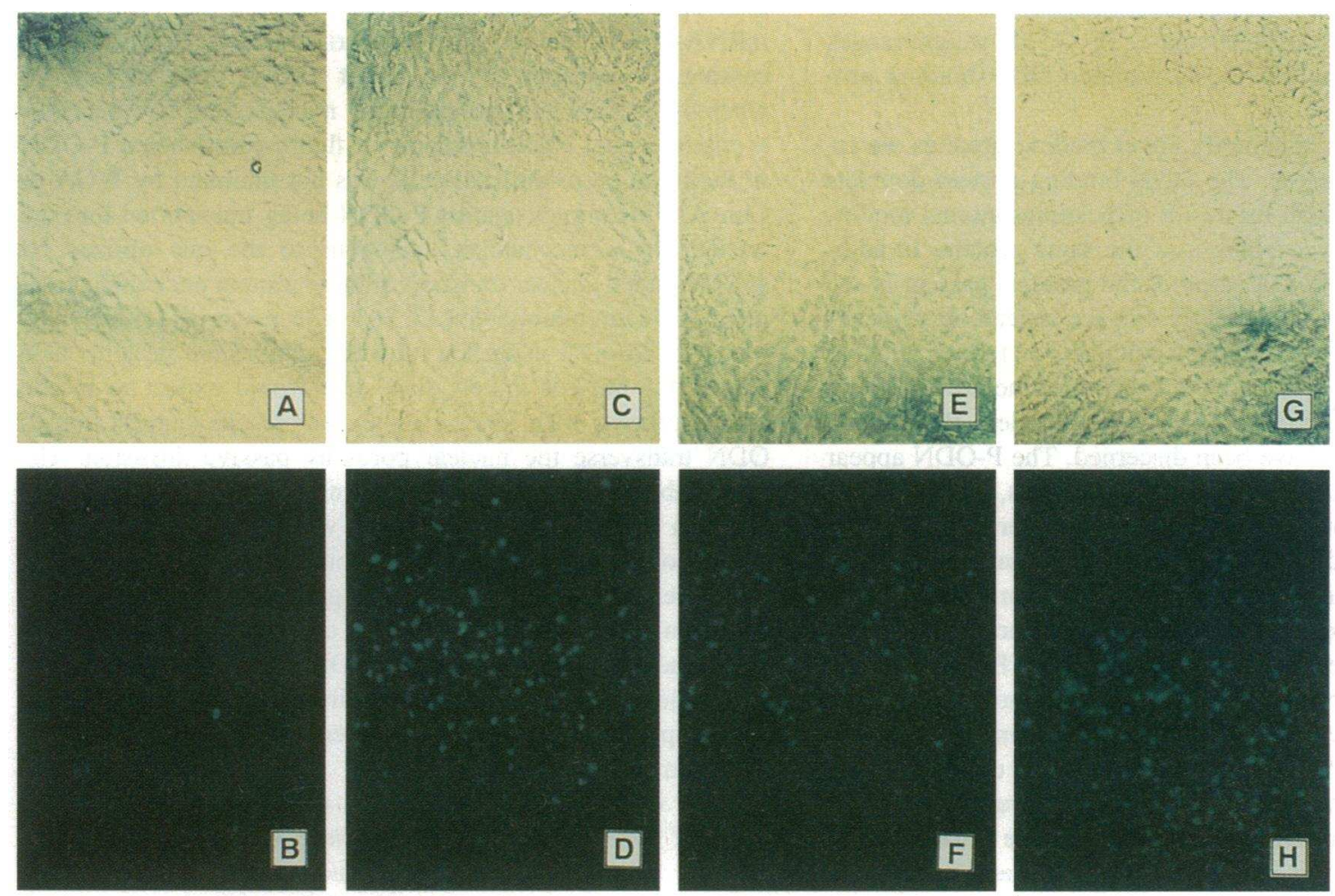

Figure 8. Nuclear import of fluorescein labeled P-ODN is not inhibited by WGA or Concanavalin A in HS 294T cells. Non-permeabilized ( $A$ and $B$ ) or triton and digitonin-permeabilized $(C$ and $D)$, or digitonin alone permeabilized cells $(E-H)$ were incubated with WGA $(E$ and $F)$ or concanavalin A ( $G$ and $H$ ) followed by fluorescein labeled c-myb antisense P-ODN. Cells were analyzed by phase contrast $(A, C, E$, and $G)$ or epifluorescense $(B, D, F$, and $H)$. In the absence of triton, few nuclei are labeled $(A$ and $B)$. In the presence of triton, which permeabilizes the nuclear membrane, virtually all nuclei are labeled $(C$ and $D)$. In cells permeabilized with digitonin, which selectively permeabilizes the cell membrane, the fluorescein labeled c-myb antisense P-ODN gain access to the nucleus regardless of which lectin the cells are preincubated with $(E-H)$. 
ence of specific surface binding proteins with which the P-ODN interact. While the latter type of data have been provided in the past $(21,22,24,33)$, our studies contrast with earlier reports in that we have identified P-ODN binding proteins in at least five major weight ranges. Finally, Gao et al have described the existence of numerous P-ODN binding proteins in the cytoplasm of the cells they were studying (26). These proteins had relatively weak affinity for the P-ODN and were distinct from nuclear P-ODN binding proteins. As a number of these cytoplasmic binding proteins have the same apparent molecular weight as the P-ODN binding proteins we report, it is tempting to speculate that these could represent internalized surface binding proteins. In accord with this hypothesis, the surface binding proteins we report also have weak affinity for the P-ODN which might in turn relate to the large number found on the cells' surface.

Why we have detected so many more binding proteins in comparison to earlier studies is not certain. Earlier reports suggested the existence of only two major types of ODN binding proteins. These were respectively, depending on the report, of $\sim 75-90$ and $\sim 25-35 \mathrm{kD}$. Some differences in our findings might be ascribed to differences in cell types studied, or to the detection strategies employed. Regarding the latter, in addition to utilizing the more commonly applied direct cross-linking methods, we have also studied metabolically labeled P-ODN binding proteins. This method, upon disruption of the crosslinks, allowed us to directly determine a physical aspect of PODN/binding protein interactions which had not been appreciated before. Specifically, since the P-ODN binding proteins do not oligomerize upon binding of their ligands a 1:1 stoichiometry of the interactions is suggested. Whether the proteins we have identified in the $\sim 75-90$ and $\sim 25-35 \mathrm{kD}$ weight ranges have identity with the previously reported ODN binding proteins is not known.

The nature of the apparently novel binding proteins we report also remains unclear. The ODN binding protein doublets visualized may represent the result of posttranslational modifications, including glycosylation, of the same protein. In addition, it is also possible that some of the proteins present in the gels do not bind the ODN directly, but are instead only associated with the ODN-binding protein complex (34). Such putative associated proteins might assist in binding of the ODN (35) or in stabilizing the ODN-binding protein complex. Regardless, several physical facts have been discerned. The P-ODN appear to bind to individual proteins of varying sizes, and there are several hundred thousand binding proteins per cell. Binding appears saturable and specific which suggests that it is receptorlike in nature. Glycosylation of the binding proteins appears important since stripping cell surfaces with neuraminidase led, in most cases to decreased P-ODN binding. Parenthetically, these studies also served to demonstrate that charge per se plays little role in specific P-ODN binding protein interactions. Finally, after binding P-ODN the binding proteins do not undergo either dimerization or oligomerization. As is true of the ODN binding proteins reported by others, the relative importance of each binding protein vis a vis P-ODN binding and internalization is not known.

Once internalized, P-ODN traffic through the endosomallysosomal pathway. This was demonstrated in two ways. Subcellular fractionation showed accumulation of ${ }^{35} \mathrm{~S}$-labeled PODN in vesicular structures and in the nucleus but significantly less in the cytoplasm. This is consistent with sequestering of P-ODN in the endosomal-lysosomal compartment and nuclear translocation upon release from the vesicles. This flow was confirmed by our electron microscope studies. To our knowledge, these studies represent the first time that intracellular trafficking of P-ODN has been visualized at the ultrastructural level. In fact, we are aware of only one other study which attempted to track ODN through cells at the electron microscope level (36) and it differed in important aspects from the studies which form the basis of this report. Whereas the earlier study employed tritium labeled phosphodiester ODN which are potentially subject to rapid degradation in the intracellular milieu, we utilized stable P-ODN. In addition, though the authors hypothesized that ODN were taken up by cells either by "potocytosis," or through caveolae they did not demonstrate ODN in surface pits or within cytoplasmic vesicles. In contrast, our data now provide direct evidence to support the hypothesis that receptor mediated endocytosis is a mechanism for importing P-ODN into cells. Unfortunately, the relative contribution of each is difficult to determine since once the P-ODN are within endosomes it is impossible to distinguish between the two mechanisms.

A potentially important implication of our studies derives from detecting labeled ODN at the heterochromatin-euchromatin border and our inability to detect P-ODN in association with ribosomes or endoplasmic reticulum, either at the ultrastructural level or in the complementary sub-cellular fractionation studies with ${ }^{35} \mathrm{~S}$-labeled material. Association of P-ODN with ribosomes or endoplasmic reticulum would be anticipated if P-ODN were inhibiting mRNA translation at the cytoplasmic level. Since no apparent relationship between ODN and ribosomes was uncovered, these results provide direct physical evidence to support the hypothesis that antisense DNA molecules exert their effects in the nucleus, perhaps through the formation of mRNA-DNA duplexes or by interfering with transcription, processing, or transport of the target mRNA. The mechanism whereby P-ODN gain access to the nucleus therefore becomes a critical issue. Nuclear import of fluorescein-labeled P-ODN in digitonin permeabilized cells was not inhibited by WGA or Con A. This argues against P-ODN being transported into the nucleus by a mechanism analogous to the one utilized by snRNPs since nuclear transport of these protein nucleotide complexes is lectin inhibitable $(37,38)$. This result is also inconsistent with P-ODN using karyophilic cytoplasmic proteins as a shuttle for nuclear import since one would expect to inhibit such a process with WGA. Rather, our results suggest that $P$ ODN transverse the nuclear pores by passive diffusion. The FITC-labeled c-myb P-ODN is assumed to be a random coil

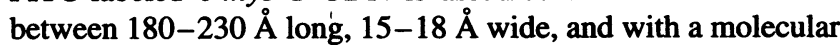
weight of 8500 (DeDionisio, personal communication). It is therefore small enough to pass through nuclear pores by passive diffusion. These studies support the conclusion of Clarenc et al who studied nuclear import of ODN into isolated nuclei or microinjected cells and suggested that the process was energy and temperature independent and therefore likely to proceed by diffusion (39).

The work reported herein both confirms and extends the work of many laboratories which have been interested in the cellular handling of oligodeoxynucleotides. By employing methods not previously utilized to address this issue we have generated novel, and potentially useful information for the design of newer and hopefully more efficient antisense ODNs. Our work predicts that ODN with nuclear localization signals may be highly efficient. However, it must be anticipated that modifications designed to increase nuclear uptake might also lead to decreased bioavailability. This paradoxical situation 
would ensue if unwanted binding to nuclear proteins led to sequestration of material $(26,39,40)$. Alternatively, modifications designed to prevent nuclear import might also have favorable qualities since such molecules would likely reach higher cytoplasmic concentrations, and should therefore have a greater chance of associating with ribosomal mRNA. This of course presumes that molecules with the desired modifications will be released intact from the vesicles in which they were imported. Accordingly, strategies aimed at increasing release of ODN from endosomal structures (41) may also be successful for similar reasons. Certainly, much remains to be learned about these compounds and their mechanism(s) of action. Studies such as the ones which form the basis of this report will hopefully contribute to this process and the further development of the molecules into useful pharmaceutical agents.

\section{Acknowledgments}

The editorial assistance of E. R. Bien, and helpful discussions with Gerald Zon (Lynx Therapeutics) is gratefully acknowledged. We also thank Dr. P. Iversen (Dept. of Pharmacology, University of Nebraska) for synthesis of ${ }^{35} \mathrm{~S}$-labeled c-myb P-ODN from precursor kindly supplied by Glen Research (Sterling, VA).

This work was supported in part by U. S. Public Health Service grants CA-54384 (A. M. Gewirtz), and CA-51083 (A. M. Gewirtz).

\section{References}

1. Neckers, L., and L. Whitesell. 1993. Antisense technology: biological utility and practical considerations. Am. J. Physiol. 265(1 Pt 1):L1-12.

2. Milligan, J. F., M. D. Matteucci, and J. C. Martin. 1993. Current concepts in antisense drug design. J. Med. Chem. 36:1923-1937.

3. Ratajczak, M. Z., J. A. Kant, N. Hijiya, J. Zhang, S. M. Luger, G. Zon, and A. M. Gewirtz. 1992. In vivo treatment of human leukemia in a SCID mouse model with c-myb antisense oligodeoxynucleotides. Proc. Natl. Acad. Sci. USA. 89:11823-11827.

4. Simons, M., E. R. Edelman, J. L. DeKeyser, R. Langer, and R. D. Rosenberg. 1992. Antisense c-myb oligonucleotides inhibit intimal arterial smooth muscle cell proliferation in vivo. Nature (Lond.). 359:67-70.

5. Kitajima, I., T. Shinohara, J. Bilakovics, D. A. Brown, X. Xu, and M. Nerenberg. 1993. Ablation of transplanted HTLV-I Tax-transformed tumors in mice by antisense inhibition of NF-kappa B. Science (Wash. DC). 259:15231523 .

6. Hijiya, N., J. Zhang, M. Z. Ratajczak, K. DeRiel, M. Herlyn, and A. M. Gewirtz. 1994. The biologic and therapeutic significance of c-myb expression in human melanoma. Proc. Natl. Acad. Sci. USA. 91:4499-4503.

7. Skorski, T., M. Nieborowska-skorska, N. C. Nicolaides, C. Szczylik, P. Iversen, R. V. Iozzo, G. Zon, and B. Calabretta. 1994. Suppression of Philadelphia 1 leukemia cell growth in mice by BCR-ABL antisense oligodeoxynucleotides. Proc. Natl. Acad. Sci. USA. 91:4504-4508.

8. Bayever, E., and P. Iversen. 1994. Oligonucleotides in the treatment of leukemia. Hematol. Oncol. 12:9-14.

9. Luger, S. M., M. Z. Ratajczak, E. A. Stadtmauer, P. Mangan, D. Magee, L. Silberstein, M. Edelstein, P. Nowell, and A. M. Gewirtz. 1994. Autografting for chronic myelogenous leukemia (CML) with c-myb antisense oligodeoxynucleotide purged bone marrow: a preliminary report. Blood. 84(Suppl 1):151a.

10. Ma, D. D. F., and T. Le Doan. 1994. Antisense oligonucleotides: are they the "magic bullets"? Ann. Int. Med. 120:161-162.

11. Stein, C. A., and Y-C. Cheng. 1993. Antisense oligonucleotides as therapeutic agents-is the bullet really magical? Science (Wash. DC). 261:1004-1012.

12. Glen Research User's Guide. 1993. p.33.

13. Dedionisio, L. 1993. Capillary gel electrophoresis and the analysis of DNA phosphorothioates. J. Chromatograpy. 652:101-108. 78 .

14. Applied Biosystems, Inc. (Division of Perkin Elmer) User Bulletin. 1994.

15. Stein, C. A., P. Iversen, C. Subashinge, J. Cohen, J. S. Wojciech, and G. Zon. 1990. Preparation of ${ }^{35}$ S-labeled polyphosphorothioate oligodeoxynucleotides by use of hydrogen phosphonate chemistry. Anal. Biochem. 188:11-16.
16. Coligan, J. E., A. M. Kruisbeek, D. H. Margulies, E. M. Shevach, and W. Strober. 1993. Current Protocols in Immunonology. Greene Publishing and WileyInterscience, New York. 6.1.7-6.1.10.

17. Gewirtz, A. M., W. Y. Xu, and K. F. Mangan. 1987. Role of natural killer cells, in comparison to $\mathrm{T}$ lymphocytes and monocytes, in the regulation of normal human megakaryocytopoiesis in vitro. J. Immunol. 139:2915-2925.

18. Lowry, O. H., N. J. Rosebrough, A. L. Farr, and R. J. Randall. 1951. Protein measurement with the Folin phenol reagent. J. Biol. Chem. 193:265-267.

19. Romano, E. L., and M. Romano. 1977. Staphylococcal protein A bound to colloidal gold: a useful reagent to label antigen-antibody sites in electron microscopy. Immunocytochemistry. 14:711-715.

20. Besterman, J. M., J. A. Airhart, R. C. Woodworth, and R. B. Low. 1981 Exocytosis of pinocytosed fluid in cultured cells: kinetic evidence for rapid turnover and compartmentation. J. Cell Biol. 91:716-727.

21. Yakubov, L. A., E. A. Deeva, V. F. Zarytova, E. M. Ivanova, A. S. Ryte, L. V. Yurchenko, and V. Vlassov. 1989. Mechanism of oligonucleotide uptake by cells: Involvement of specific receptors? Proc. Natl. Acad. Sci. USA. 1986:6454-6458.

22. Loke, S. L., C. A. Stein, X. A. Zhang, K. Mori, M. Nakanishi, C. Subashinge, J. S. Cohen, and L. M. Neckers. 1989. Characterization of oligonucleotide transport into living cells. Proc. Natl. Acad. Sci. USA. 86:3474-3478.

23. Iversen, P. L., S. Zhu, A. Meyer, and G. Zon. 1992. Cellular uptake and subcellular distribution of phosphorothioate oligonucleotides into cultured cells. Antisense Res. Dev. 2:211-222.

24. Geselowitz, D. A., and L. M. Neckers. 1992. Analysis of oligonucleotide binding, internalization and intracellular trafficking utilizing a novel radiolabeled crosslinker. Antisense Res. Dev. 2:17-25.

25. Stein, C. A., J. L. Tonkinson, L.-M. Zhang, L. Yakubov, J. Gervasoni, R. Taub, and S. A. Rotenberg. 1993. Dynamics of the internalization of phosphodiester oligodeoxynucleotides in HL60 cells. Biochemistry. 32:4855-4861.

26. Gao, W., C. Storm, W. Egan, and Y. Cheng. 1992. Cellular pharmacology of phosphorothioate homooligodeoxynucleotides in human cells. Mol. Pharmacol. 43:45-50.

27. Bennett, R. M. 1993. As nature intended? The uptake of DNA and oligonucleotides by eukaryotic cells. Antisense Research and Development. 3:235-241.

28. Cohen, N. D. and M. Thomas. 1982. Biotin transport into fully differentiated 3T3-L1 cells. Biochem. Biophys. Res. Commun. 108:1508-1516.

29. Bowers-Komro, D. M., and D. B. McCormick. 1985. Biotin uptake by isolated rat liver hepatocytes. In Dakshinamurti. K. Bhagavan and H. N. Biotin editors. Ann NY Acad Sci. 447:350-358.

30. Chalifour, L. E., and K. Dakshinamurti. 1982. The characterization of the uptake of avidin-biotin complex by HeLa cells. Biochim. Biophys. Acta. 721:6469.

31. Pardridge, W. M. and R. J. Boado. 1991. Enhanced cellular uptake of biotinylated antisense oligonucleotide or peptide mediated by avidine, a cationic protein. FEBS (Fed. Euro. Biochem. Soc.) Lett. 288:30-32.

32. Gao, W-Y., J. W. Jarroszewski, J. S. Cohen, and Y-C. Cheng. 1990. Mechanisms of inhibition of herpes simplex virus type 2 growth by 28-mer phosphorothioate oligodeoxycytidine. J. Biol. Chem. 265:20172-20178.

33. Bennett, R. M., G. T. Gabor, and M. Merritt. 1985. DNA binding to human leukocytes. J. Clin. Invest. 76:2182-2190.

34. Burton, J., C. K. Goldman, P. Rao, M. Moos, and T. A. Waldmann. 1990. Association of intercellular adhesion molecule 1 with the multichain high-affinity interleukin 2 receptor. Proc. Natl. Acad. Sci. USA. 87:7329-7333.

35. Roghani, M., A. Mansukhani, P. Dell'Era, P. Bellosta, C. Basilico, D. B. Rifkin, and D. Moscatelli. 1994. Heparin increases the affinity of basic fibroblas growth factor for its receptor but is not required for binding. J. Biol. Chem. 269:3976-3984.

36. Zamecnick, P., J. Aghajanian, M. Zamecnick, J. Goodchild, and G. Witman. 1994. Electron micrographic studies of transport of oligodeoxynucleotides across eukaryotic cell membranes. Proc. Natl. Acad. Sci. USA. 91:3156-3160.

37. Agutter, P. S., and D. Prochnow. 1994. Nucleocytoplasmic transport. Biochem. J. 300:609-618.

38. Finlay, D. R., D. D. Newmeyer, T. M. Price, and D. J. Forbes. 1987 Inhibition of in vitro nuclear transport by a lectin that binds to nuclear pores. $J$. Cell Biol. 104:189-200.

39. Clarenc, J-P., B. Lebleu, and J-P. Leonetti. 1993. Characterization of the nuclear binding sites of oligodeoxyribonucleotides and their analogues. J. Biol. Chem. 286:3600-3604.

40. Chin, D. J., G. A. Green, G. Zon, F. C. Szoka, and R. M. Straubinger. 1990. Rapid nuclear accumulation of injected oligodeoxyribonucleotides. New Biol. 2:1091-1100.

41. Morishita R, G. H. Gibbons GH, K. E. Ellison, M. Nakajima, H. von der Leyen H, L. Zhang, Y. Kaneda, T. Ogihara, V. J. Dzau. 1994. Intimal hyperplasia after vascular injury is inhibited by antisense cdk 2 kinase oligonucleotides. $J$. Clin. Invest. 93:1458-1464. 